\title{
Clinical, EEG and neuroimaging features of ictal epileptic headache
}

\author{
NZR Radojkovic Gligic ${ }^{*}$, KKK Kacar, SMA Atic, BW Vekic \\ From The European Headache and Migraine Trust International Congress \\ London, UK. 20-23 September 2012
}

\section{Introduction}

Migraine end epilepsy have common pathophysiologic mechanisms and share essential and defining attributes which distinguish them from other common neurological disorders. They are both characterized by paroxysmal symptoms and are, therefore, episodic disorders. Occipital lobe to be the brain structures most responsible for development of migraine and occipital lobe epilepsies Both are characterized by visual symptoms followed by headache and other autonomic symptoms. Recognition of headache as an epileptic manifestation per se still represents a challenge.

\section{Methods}

This study included consecutive 89 patients with IEH= ictal epileptic headache,at our hospital and our diagnostical department - MRI and EEG.

\section{Results}

EEG recordings high voltage rhythmic $11-12 \mathrm{~Hz}$ activity with intermingled spikes over the right TO regions. Other -high voltage theta activity intermingled with sharp waves over occipital region. And third bilateral SWC.Brain MRI showed secondary brain lesion in the right TPO region with restricted diffusion in the right occipital region.

\section{Conclusion}

IEH be used to classify the events in wich headache represent the only ictal epileptic feature These rare cases should be classified as autonomic epilepsy.

Published: 21 February 2013

Hospital for cerebrovascular desease St. Sava, Serbia and Montenegro
References

1. European headache school:. Belgrade; 2012.

2. Lenox WG, Lennox MA:. Epilepsy and related disorders Little, Brown, Boston; 1960.

3. Perucca P, Teryaghi M, Manni R: Status epilepticus migrainosus clinical electroencephysiologic, and imaging characteristics neurology. 2010.

4. Teryano MG, Pietrini L, Milione FF: Migraine and intercalated seizures with occipital EEG paroxisms:observations on a family. headache 1986.

doi:10.1186/1129-2377-14-S1-P156

Cite this article as: Radojkovic Gligic et al:: Clinical, EEG and

neuroimaging features of ictal epileptic headache. The Journal of

Headache and Pain 2013 14(Suppl 1):P156.
Submit your manuscript to a SpringerOpen ${ }^{\circ}$ journal and benefit from:

- Convenient online submission

- Rigorous peer review

- Immediate publication on acceptance

- Open access: articles freely available online

- High visibility within the field

- Retaining the copyright to your article

Submit your next manuscript at $>$ springeropen.com

\section{SpringerOpen ${ }^{\circ}$}

C 2013 Radojkovic Gligic et al; licensee Springer. This is an Open Access article distributed under the terms of the Creative Commons Attribution License (http://creativecommons.org/licenses/by/2.0), which permits unrestricted use, distribution, and reproduction in any medium, provided the original work is properly cited. 